Agro-Science Journal of Tropical Agriculture, Food, Environment and Extension Volume 12 Number 3 September 2013 pp. $35-42$

ISSN 1119-7455

\title{
NUTRITIONAL EVALUATION OF WHEAT CAKES ENRICHED WITH EDIBLE AFRICAN TERMITES (MACROTERMES NIGERIENSIS)
}

\author{
${ }^{1}$ Ojinnaka, M.C., ${ }^{2}$ Ofoelo, M.U., ${ }^{3}$ Ezenwa, L.I \\ ${ }^{1}$ Department of Food Science \& Technology, Michael Okpara University of Agric. Umudike \\ ${ }^{2}$ Department of Food Science \& Technology, Imo State University, Owerri \\ ${ }^{3}$ Department of Environmental Mgt. \& Toxicology, Michael Okpara Univ. of Agric. Umudike
}

\begin{abstract}
The nutritional and economic value of Termites Macrotermes nigeriensis is often neglected and as such the effect of substitution of wheat flour with the milled paste of edible African termite, $M$. nigeriensis in cake production was studied. The M. nigeriensis paste obtained was used at different levels of substitution $10 \%$ $20 \%$ with wheat flour for cake production. The sensory attributes including colour, taste, texture, flavour, aroma, appearance and general acceptance were evaluated by twenty member semi-trained panelist using a 9point Hedonic scale in which one represents the least score (dislike extremely) and nine the most desirable score (liked extremely) for any attribute. The result of the organoleptic properties showed that no significant difference $(p<0.05)$ existed in all the attributes tested. However the sample containing $5 \%$ termite paste was most preferred. The proximate composition of the cake samples were determined using standard methods. The result of the proximate analysis showed the protein content of the cake samples increased as the level of incorporation of the edible African termite paste increased. The protein contents of the cake samples ranged from 10.04 to 19.57\%. There was significant difference in the moisture content of the cake samples which ranged from $2.44-3.31 \%$. There were significant difference in the magnesium, potassium and phosphorous values of the cake samples. The antinutrients (tannins, phytate, saponins, oxalate) determined all had low values signifying that the cake product will pose no threat to human consumption.
\end{abstract}

Keywords: African termite, cake, proximate, mineral, anti-nutrients

\section{INTRODUCTION}

Insects constitute about $75 \%$ of all known animal species (Yoloye, 1998). Though some insect species are known to be poisonous (Adamolekun, 1993), a good number of them are edible (Meyer-Rochow, 2010). Edible insects have played an important role in the history of human nutrition (Lyon, 1991). They are important dietary components in many developing countries; the commonly consumed insects being locust, termites, grasshoppers, weevil, bee, beetle, and caterpillar. Many studies have also shown that edible insects contain appreciable amount of nutrients such as protein and high fibre. They have also been found to be rich sources of fats, vitamins and minerals, especially iron and zinc (Malaisse and Parents, 1980). These edible insects are an excellent source of protein, calcium, vitamins and mineral. They even contain more healthy polyunsaturated fat than fish or fowl. Edible insects have served as traditionally and nutritionally important food for Africans, Asians, Australians and Latin Americans for many years (Allotey and Mpuchane, 2003).
Insects are high in protein, energy (calories) and various vitamins and minerals (Motshegwe et al., 1998). The health situation in Africa is characterized by high rate of malnutrition and most common of these is protein deficiency (WHO, 1999). This has been aggravated by prohibitive prices and excessive dependence on conventional protein sources (Olaofe et al., 1998).

Entomophagy (consumption of insects by human) has gained prominence in recent years as a result of drought and poor economic conditions. It may have undoubtedly played an important role in reducing kwashiorkor among young children of poor parents. It has been earlier reported that because of the high cost of conventional protein foods, protein energy malnutrition is widespread in rural Nigeria. Studies have showed that most Nigerians have had direct or indirect experience with entomophagy, although it is more prevalent in the rural than urbanized areas. Large quantities of insects, especially grasshoppers, caterpillars and termites are brought from rural areas for sale in urban markets (Ademolekun, 1993). 
Belluco et al., (2013) have reported that increasing world population worsens the serious problem of food security in developing countries as well as in industrialized countries, where the problem of food security is of minor concern. They further stated that health problems related to food refer to two main factors: food safety and environmental sustainability of food production and suggested that for these reasons, new ways must be found to increase yields while preserving food quality, natural habitats, and biodiversity. Insects could be of great interest as a possible solution due to their capability to satisfy the two different requirements: (i) they are an important source of protein and other nutrients; (ii) their use as food has ecological advantages over conventional meat and, in the long run, economic benefits (Belluco et al., 2013). There should be an upsurge of interest in the use of insects as food because many are nutritionally, economically and ecologically important.

$M$. nigeriensis is a favourite delicacy in many African countries and it is a winged adult termite of the order, Isoptera and family, Termitidae. Although $M$. nigeriensis is an eusocial insects with a typical colony containing nymphs (semi-mature young), workers, soldiers and the reproductive individual (alates) of both genders (Ojiako and Igwe, 2006). The alates are the winged adults that are commonly caught and consumed. They are the fully developed adult stage of termites. There exist fair variations among the winged adults, probably due to geographical locations or developmental stages. There are many species of termites such as $M$. nigeriensis, M. notalensis, M.subhylinus or $M$. belicosus. However, they are all simply termed termites, winged termites or Macrotermes specie (Mbah and Elekima, 2007). The winged termites are known locally in various parts of Nigeria by different names such as 'aku' in Ibo, 'chinge' in Hausa and 'Esusu' in Yoruba (Fasoranti and Ajiboye, 1993). M nigeriensis is enjoyed in most parts of Nigeria. They are sold in markets after being well prepared by washing, salting to taste and mild frying or roasting. It can be eaten raw. It has nutty flavour when prepared. Oil is not usually needed during frying, since their bodies are naturally oily. The delicious taste of termite make them a good meal for all groups. Fried termite meal is also suitable for European palate (Igwe et al., 2011). The crude protein content of $35.88 \%$ obtained from the species was higher than the $14.2 \%$ recorded for Marotermes subhyalinus (Defoliart, 1989), indicating that $M$. nigeriensis is a good source of protein for man and animals.

Considering the economic, nutritional and ecological advantages of the traditional food sources, its promotion deserves more attention both from national government and assistance programmes. The present study h work was undertaken to develop a process of incorporating edible African termite paste into wheat cake and to study the nutritional, anti-nutritional and organoleptic properties of the wheat cake samples enriched with $M$. nigeriensis.

\section{MATERIALS AND METHODS}

The adult termites (Macrotermes nigeriensis) were collected from the field during the early rainy season from March - May 2014. The termites were oven dried at $40^{\circ} \mathrm{C}$ to constant weight and then milled into an oily paste at the Central Laboratory of National Root Crops Research Institute Umudike, Abia State Nigeria. The wheat cake samples enriched with termite were developed with substitution of the wheat flour with the dried milled termite at $0 \%, 5 \%$, $10 \%$ and $20 \%$ substitution levels. The Wheat-termite cake samples were prepared using the method of Ceserani and Kinton, (2008). Below is the table for the blend formulation.

\section{Proximate Composition Analysis}

The moisture content, crude protein content and ash content of the cake samples were determined by the methods of AOAC (1990). Crude fibre was assayed by the method reported by James (1995). Crude fat was determined using the method of Min and Boff (2003). The nitrogen-free extract (i.e. the soluble carbohydrate) was calculated by difference. The parameters were determined in triplicates.

\section{Evaluation of anti-nutritional factors}

The oxalate value was determined using the permanganate titration method described by Onwuka (2005)

Phytate was determined using the oberlease Spectrophotometer method described by Onwuka, (2005)

Tannin content of the sample was determined by Folin Denis Colometric method (Krik and Sawyer, (1998).

Saponin was determined using the double solvent extraction gravimetric method (Harborne, 1973.

\section{Mineral Content Analysis}

The mineral components were analyzed using an Atomic Absorption Spectrophotometer (AAS, Model SP9, Pychicham UK)

\section{Statistical Analysis}

The data collected from the experiment were subjected to analysis of variance (Iwe 2002). 
RESULTS AND DISCUSSION

Proximate compositions of cake samples enriched with $M$. nigeriensis.

The result of the proximate composition of wheat cake samples enriched with $M$. nigeriensis is presented in Table 1. The baked cake samples varied significantly $(\mathrm{p} \leq 0.05)$ in its proximate composition. The result of the proximate analysis of the cake samples enriched with $M$. nigeriensis should that the protein, fat, ash and carbohydrate contents of the cake samples increased significantly $(\mathrm{p}<0.05)$ as the level of substitution with the milled paste of $M$. nigeriensis increased, except for moisture content which decreased significantly.

Moisture Content -The moisture content of the wheat-termite cake samples ranged from $2.44 \%$ to $3.31 \%$. The result showed that as the level of substitution of the $M$. nigeriensis increased in the baked cake samples the moisture content decreased. The moisture content of the samples was significantly different $(\mathrm{P} \leq 0.05)$. The moisture content is an index of water activity (Olutiola et al., 1991) and is used as a measure of stability and susceptibility to microbial contamination (Uraih and Izuagbe, 1990).

Table 1: Blend Formulation of Cake Samples Enriched With M. nigeriensis

\begin{tabular}{llllll}
\hline SAMPLE & A & B & C & D & E \\
\hline WHEAT FLOUR & 100 & 95 & 90 & 85 & 80 \\
M.nigeriensis paste & - & 5 & 10 & 15 & 20 \\
\hline
\end{tabular}

Table 1: Proximate Composition of Cake Samples Enriched with M. nigeriensis

\begin{tabular}{|c|c|c|c|c|c|c|}
\hline & Samples & & & & & \\
\hline Parameters & $\begin{array}{l}\text { A } \\
\text { L.S.D }\end{array}$ & B & & $\mathbf{C}$ & D & $\begin{array}{l}\mathrm{E} \\
2.44^{\mathrm{b}} \pm 0.02\end{array}$ \\
\hline Moisture (\%) & $3.31^{\mathrm{a}} \pm 0.050 .06$ & $2.48^{\mathrm{b}} \pm 0.02$ & $2.46^{\mathrm{b}} \pm 0.21$ & $2.44 \pm 0.02^{\mathrm{b}} 2$ & $2.44^{\mathrm{b}} \pm 0.02$ & $19.57^{\mathrm{a}} 5 \pm 0.11$ \\
\hline Protein $(\%) 0.36$ & $10.04^{\mathrm{e}} \pm 0.08$ & $12.25^{\mathrm{d}} \pm 0.19$ & $14.81^{\mathrm{c}} \pm 0.21$ & $15.40^{\mathrm{b}} \pm 0.35$ & $19.57^{\mathrm{a}} \pm 0.11$ & $10.84^{\mathrm{a}} 5 \pm 0.02$ \\
\hline Fat $(\%) \quad 0.26$ & $8.67^{\mathrm{d}} \pm 0.04$ & $9.26^{\mathrm{c}} \pm 0.26$ & $9.75^{\mathrm{b}} \pm 0.07$ & $10.63^{\mathrm{a}} \pm 0.18$ & $10.84^{\mathrm{a}} \pm 0.02$ & $6.25^{\mathrm{a}} \pm 0.06$ \\
\hline Ash $(\%) 0.18$ & $4.21^{\mathrm{e}} \pm 0.06$ & $4.67^{\mathrm{d}} \pm 0.04$ & $5.24^{\mathrm{c}} \pm 0.07$ & $5.75^{\mathrm{b}} \pm 0.10$ & $6.25^{\mathrm{a}} \pm 0.06$ & $73.772 \pm 0.0$ \\
\hline arbohydrate $(\%) 0.89$ & $60.90^{\mathrm{e}} \pm 0.12$ & $65.78^{\mathrm{d}} \pm 0.51$ & $67.74^{\mathrm{c}} \pm 0.16$ & $72.00^{\mathrm{b}} \pm 0.94$ & $73.77 \pm 0.16^{\mathrm{a}}$ & $0.15 \pm 0.16^{\mathrm{a}}$ \\
\hline \multicolumn{7}{|c|}{ \% Level of termite paste added } \\
\hline \multicolumn{7}{|c|}{ Key sample $A=0 \%$ termite paste } \\
\hline \multicolumn{7}{|c|}{$\mathrm{B}=5 \%$ termite paste } \\
\hline \multicolumn{7}{|c|}{$\mathrm{C}=10 \%$ termite paste } \\
\hline \multicolumn{7}{|c|}{$\mathrm{D}=15 \%$ termite paste } \\
\hline $\mathrm{E}=20 \%$ termite $\mathrm{p}$ & & & & & & \\
\hline
\end{tabular}

Table 2: Mineral Composition of Cake Samples Enriched with M. nigeriensis Key sample

\begin{tabular}{llllll}
\hline \multicolumn{7}{c}{ Samples } \\
\hline Parameters L.S.D & A & B & C & D & E \\
Tannins (\%) & $0.109 \pm 0.0$ & $0.103 \pm 0.0$ & $0.098 \pm 0.0$ & $0.092 \pm 0.0$ & $0.092 \pm 0.0-$ \\
Phytate (\%) & $0.11 \pm 0.0$ & $0.10 \pm 0.0$ & $0.5 \pm 0.05$ & $0.15 \pm 0.05$ & $0.08 \pm 0.0-$ \\
Saponins (\%) & $0.13 \pm 0.01$ & $0.11 \pm 0.01$ & $0.09 \pm 0.02$ & $0.05 \pm 0.02$ & $0.05 \pm 0.01-$ \\
Oxalate (\%) & $0.086 \pm 0.01$ & $0.072 \pm 0.01$ & $0.072 \pm 0.01$ & $0.072 \pm 0.01$ & $0.052 \pm 0.01-$ \\
\hline
\end{tabular}

* Means in the same rows with the same superscripts are not significantly different at $(\mathrm{P} \leq 0.05)$

\% Level of termite paste added

$\mathrm{A}=0 \%$ termite paste

$$
\begin{aligned}
& B=5 \% \text { termite paste } \\
& C=10 \% \text { termite paste } \\
& D=15 \% \text { termite paste } \\
& E=20 \% \text { termite paste }
\end{aligned}
$$


Protein Content - The protein content of the wheat cake was observed to increase progressively to the proportion of the percentage of the milled termite paste added. The protein content of the cake samples ranged from $10.04 \%$ (sample A) to $19.57 \%$ (sample E). From the result, the protein content of the cake sample E ( $80 \%$ wheat flour and $20 \%$ M. nigeriensis) was the highest when compared to the protein content of the other samples. Sample E with the protein content, $19.57 \%$ was higher than the other samples. The value corresponded with Igwe (2011) who reported that edible termite contains $20.94 \%$ protein. Edible insects have been shown to have higher protein content on a mass basis than other animal and plant foods such as beef, chicken, fish, soybeans and maize (Teffo et al., 2007). Similar findings on increasing protein contents in foods enriched with edible insects were reported by Idolo (2010) who worked on the nutritional and quality attributes of wheat buns enriched with the larvae of
Rhynchophorus phoenicis F. The larvae of Rhychophorus phoenicis have been reported (Ande, 1991; Fasoranti, 1997) to be a rich source of digestible proteins able to make up for the dietary imbalance as they form real sources of food for man and other animals. Kiin-Kabari and Ogbonda (2013) worked on the production, proximate and sensory evaluation of Rhynchophorus phoenicis (F) larva paste in meat pie and sandwich and reported that the protein content of the larva ranged from $20.45 \%$ in the Rhynchophorus paste and decreased to $9.9 \%$ in the commercial sandwich. Kinyuru et al., (2009) reported $15.63 \%$ protein in wheat termite buns $(5 \%$ milled dried termite; $95 \%$ wheat flour) the result is comparable to that obtained in sample B $(5 \%$ termite paste; $95 \%$ wheat flour) which had $12.25 \%$ protein content. The nutritional value of food largely depends on the quality of the protein that it contains. This in turn is determined to a great extent, by the amino acid composition of the samples.

Table 3: Antinutritional Properties of Cake Samples Enriched with M. nigeriensis

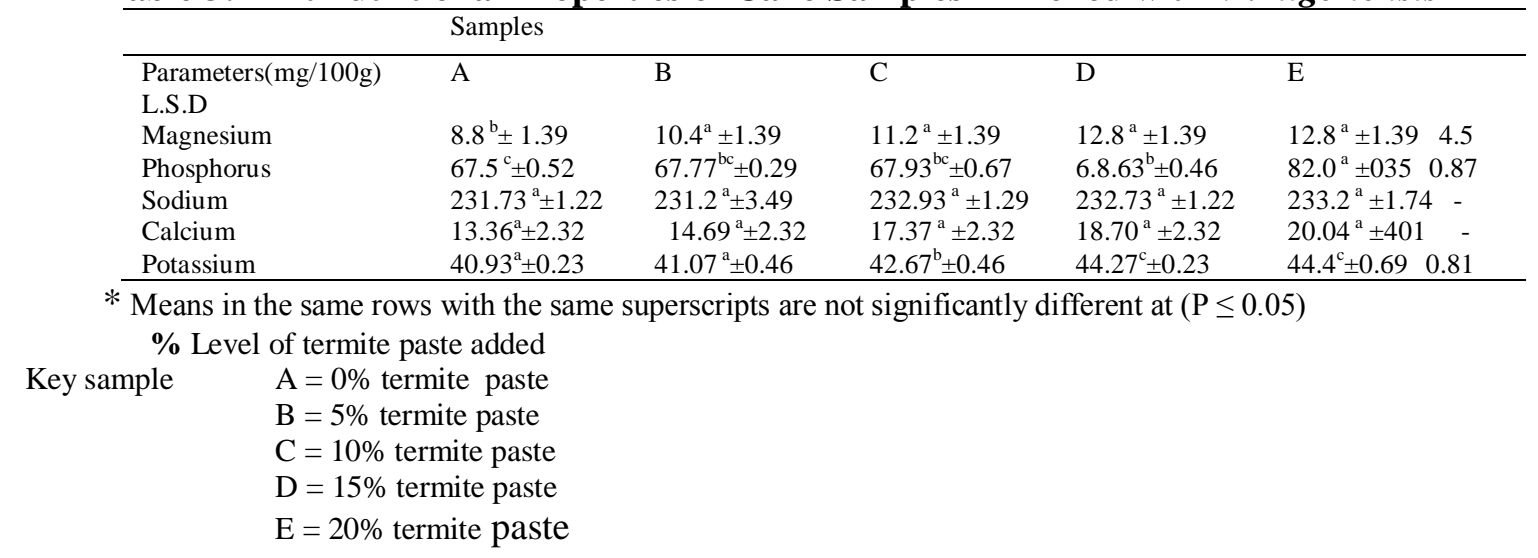

Table 4: Sensory Properties of Cake Samples Enriched with M. nigeriensis

\begin{tabular}{|c|c|c|c|c|c|}
\hline & & Samples & & & \\
\hline Parameters L.S.D & A & B & $\mathbf{C}$ & D & $\mathbf{E}$ \\
\hline Tannins (\%) & $0.109 \pm 0.0$ & $0.103 \pm 0.0$ & $0.098 \pm 0.0$ & $0.092 \pm 0.0$ & $0.092 \pm 0.0-$ \\
\hline Phytate (\%) & $0.11 \pm 0.0$ & $0.10 \pm 0.0$ & $0.5 \pm 0.05$ & $0.15 \pm 0.05$ & $0.08 \pm 0.0$ \\
\hline Saponins (\%) & $0.13 \pm 0.01$ & $0.11 \pm 0.01$ & $0.09 \pm 0.02$ & $0.05 \pm 0.02$ & $0.05 \pm 0.01$ \\
\hline Oxalate $(\%)$ & $0.086 \pm 0.01$ & $0.072 \pm 0.01$ & $0.072 \pm 0.01$ & $0.072 \pm 0.01$ & $0.052 \pm 0.01-$ \\
\hline
\end{tabular}

Acceptability

* Means in the same rows with the same superscripts are not significantly different at $(\mathrm{P} \leq 0.05)$

$\%$ Level of termite paste added

Key sample $\quad \mathrm{A}=0 \%$ termite paste

$\mathrm{B}=5 \%$ termite paste

$\mathrm{C}=10 \%$ termite paste

$\mathrm{D}=15 \%$ termite paste

$\mathrm{E}=20 \%$ termite paste

Fat Content - The fat content of the samples ranged from $8.67 \%$ to $10.84 \%$. The fat content of the samples differed significantly $(\mathrm{P} \leq 0.05)$. The fat content increased as the level of substitution with the edible termite paste increased. Kiin-Kabari (2013) reported fat content of $19.6 \%$ in pie enriched with $R$. phoenicis and $16.3 \%$ in $R$. phoenicis enriched sandwich. It has been reported that insects are good nutritional food source of fat and protein 
(Raksakantong et al., 2010; Bednářová et al., 2013, 2014).

Ash Content - The ash content of the samples showed that as the substitution of edible termite in the baked cake samples increased the ash content of the samples also increased. A relative high value of ash $(6.25 \%)$ was observed when compared to other reported values for meat and egg products (Watt and Merril, 2000). The ash content of the samples ranged from $4.21 \%$ ( sample A) to $6.25 \%$ (sample E). Similar values were obtained by Igwe (2011) who reported ash content of $7.60 \%$ on dry basis. Ash is a non- organic compound containing mineral content of food and nutritionally it aids in the metabolism of other organic compounds such as fat and carbohydrate (Mcwilliam, 1978).

Carbohydrate Content -The carbohydrate content of the samples increased in relation to the fat content in the baked cake samples. Carbohydrate and fats are important nutritive elements in the human body. Cake with $100 \%$ wheat flour had the least energy value. This could probably be due to the lower fat content of the cake samples as fat have been reported to have double amount of energy values. According to Ihekoronye and Ngoddy (1985), the energy value of food is much more related to fat than carbohydrate. Messiaen (1992) reported that the higher the protein, fat, and ash content, the lower the carbohydrate content.

\section{Mineral composition of cake samples enriched with $M$. nigeriensis.}

The result of the mineral contents of the cake samples enriched with $M$. nigeriensis is presented in Table 2. The magnesium content of the samples ranged from $8.81 \mathrm{mg} / 100 \mathrm{~g}$ to $12.8 \mathrm{mg} / 100 \mathrm{~g}$. The result showed that as the concentration of the $M$. nigeriensis increased, the magnesium content of the samples increased. Sample A had significantly $(\mathrm{p}<0.05)$ ower value $(4.93 \mathrm{mg} / 100 \mathrm{~g})$ in the potassium content than the other samples. The result showed that $M$. nigeriensis is a good source of minerals. These minerals are known to play important metabolic and physiological roles in the living system as anti-oxidant enzyme co-factor (Talwar, 1989).

Magnesium is needed for many biochemical reactions in the body. It helps to maintain normal muscles and nerve function, keeps heart rhythm steady, support a healthy immune blood and regulate blood sugar levels (Saris et al., 2000). The mineral content of calcium and sodium showed no significant difference. The potassium content of sample A $(40.93 \mathrm{mg} / 100 \mathrm{~g})$ and B $(41.07 \mathrm{mg} / 100 \mathrm{~g})$ did not differ significantly but.it has been reported that magnesium, zinc and selenium prevent cardiomyopathy, muscle degeneration, growth retardation, impaired spermatogenesis, immunogical dysfunction and bleeding disorder (Igwe et al., 2011).

Anti-nutritional composition of wheat cake samples enriched with $M$. nigeriensis.

The anti- nutritional composition of cakes enriched with $M$. nigeriensis. Anti-nutrients such as oxalates, tannins, phytate and hydrogen-cyanide have been reported in edible insects in Nigeria (Ekpo et al., 2010, Ifie and Emeruwa, 2011). The anti-nutrients analysed in the samples were tannin, oxalates, phytate and saponin. The result of the anti-nutritional composition of the samples showed that the antinutrients were not significantly different $(\mathrm{P} \leq 0.05)$ in their quantitative values. All the values obtained from the cake samples appeared to be low and are comparable to the values reported for commonly consumed foods (Ezeagu, 2005).. The saponin contents of the cake samples were very low suggesting that they pose no threat to people who consume them. Saponin has been reported to lower plasma cholesterol concentration (Topping et al., 1980). Oxalates are known to sequester and precipitate some useful metallic elements, thus making them unavailable for absorption in human system (Groff et al., 1995). The lethal dose of oxalate is between 200 and $500 \mathrm{mg} / 100 \mathrm{~g}$ (Pearson, 1963). Phytate, like oxalates limit the availability of some notable minerals like magnesium, iron and even calcium (Groff el al., 1995). Phytic acid has also been implicated in the removal of phosphorus and causing indigestion and flatulence in human system (Ndubuakaku et al., 1989). Low levels of tannin were also observed in the cake samples. Onwuka (2005) reported that the presence of tannins can cause browning or other pigmentation problems in both fresh food and processed products. Tannins possess both toxic and therapeutic functions. They are as in that they coagulate protein. Tannins are capable of lowering available protein by antagonistic competition and can therefore elicit deficiency syndrome (Ekpo, 2004).

The results of the anti-nutrients showed that the cake samples enriched with $M$. nigeriensis were low in toxic substances and are therefore, good for human consumption. The values of tannins, phytates, saponins and oxalates in the samples were negligible.

Sensory evaluation of wheat cake samples enriched with $M$. nigeriensis.

The results of the sensory attributes of wheat-termite composite cakes are presented in Table 4. The results of the colour of the samples showed that sample A (100\% wheat flour) had the best colour with the value of $6.50 \pm 0.14$. It could be as a result of high gluten and gliadin present in the sample that helped to increase its appearance in terms of colour. There was no significant difference $(\mathrm{P}>0.05)$ in the colour of the samples. It was also observed that the appearance of the cake samples decreased in colour 
as the level of addition of edible termite paste increased. This was also reported by Kinyuru et al., (2009) Colour is a very important parameter in judging properly baked biscuits it does not only reflect the suitable raw material used for the preparation but also provides information about the formulation and quality of the product (Abu-salem and Abou- Arab, 2011). During baking, Maillard reactions occur among sugar and the amino acids, peptides or proteins from other ingredients in the baked products, causing browning ( Rickard and Sjodin, 1984). Intense brown color was observed with the increase in termite concentration suggesting an increase in protein content. The Maillard reactions also affect the taste and aroma the baked products (Walter et al., 2006). Similar trends were also reported by Idolo (2010) with wheat buns enriched with larva of palm weevil. The sample containing $15 \% R$. Phoenicis and $85 \%$ wheat flour was less preferred by the members of the sensory panel.

The taste of the samples showed that the organoleptic quality of the cake samples in terms of taste decreased as the concentration of edible termite increased in the cake samples with sample E having the least value $(6.15 \pm 1.84)$. There was also no significant difference $(p>0.05)$ in the flavour of the cake samples. The sample A was observed to have the highest value in terms of flavour. This could be as a result of non-addition of edible termite in the cake samples. Flavour is the main criterion that makes the product to be liked or disliked (Abu-Salem and Abou-Arab, 2011). The sensations of taste and smell are functions of flavour which is a complex of sensations (Iwe, 2007). Food flavour Ihekoronye and Ngoddy, 1985) arises from a subtle interaction of taste and aroma, which imparts a pleasing or displeasing sensory experience to a consumer. It is the flavour of a food that ultimately determines its acceptance or rejection, even though its appearance evokes the initial response. The texture of the samples also showed that sample A had the best texture when compared to the other samples. It could be as a result of increase in milled edible termite that affected the crispness of the cake samples.

The general acceptability of the samples showed that sample A had the highest value for general acceptability with a value of 7.10 while sample E had the least value of 6.30. The higher edible termite in sample E could be the cause of low acceptability of the cake samples by the consumer despite its nutritional advantage over to the other cake samples. Kinyuru et al., (2009) also reported low acceptability for wheat-termite buns (20\% termite; $80 \%$ wheat flour) with value of 4.2 on a 7 point hedonic scale Consequently public enlightenment is needed on the nutritional benefits of supplementation of wheat flour with M. nigeriensis in the production of cake.

\section{REFERENCE}

Adamolekun, B. (1993). Anaphe venata entomophagy and seasonal ataxic syndrome in southwest Nigeria. The Lancet, 341, 629. http://dx.doi.org/10.1016/01406736(93)90388-W

Allotey, J. and Mpuchane, S. (2003). Utilization of useful insects as a food source. Afr. J. of Food Agr. Nutr. and Dev. 3: 2.

Abu-Salem, F.M. and Abou-Arab, A.A. (2011). Effect of supplementation of Bambara groundnut (Vigna subterranean L.) flour on the quality of biscuits. Afr. J. Food Sci. 5(7):376-383

Ande, A.T., 1991. Some aspects of the Biology of Insects (Lepidoptra: Saturnidae, Coleoptera: curculionidae). Nig. J. Entom., 24: 106-129.

AOAC. (2000). Association of Official Analytical Chemists. Official methods of Analysis (Vol. II 17th edition) of AOAC International.Washington,DC, USA.

Bednarova M., Borkovcova M., Mlcek J., Rop O., and Zeman L. (2013). Edible insects species suitable for entomophagy under condition of Czech Republic. Acta Univ. Agric. Silvic. Mendel. Brun. 61: (3) :587593.

Bednarova M., Borkovcova M., and Komprda T.(2014). Purine derivate content and amino acid profi le in larval stages of three edible insects. J. Sci. Food Agric. 94: 7176.

Belluco, S., Losasso, C., Maggioletti, M., Alonzi, C., Paoletti, M.G. and Ricci, A. ( 2013 ). Edible Insects in a Food Safety and Nutritional Perspective: A Critical Review. In comprehensive Reviews in Food Science and Food Safety., 12 (3): 296 - 313

Bukkens, S.G.F. (1997). The nutritional value of edible insects. Ecol. food. Nutri. 36:287-319 Ceserani, V. and Kinton, R. ( 2008). Practical Cooking $10^{\text {th }}$ Edn. John Wiley and sons, New York .

DeFoliart, G.R. (1989). The human use of insects as food and as animal feed. Bulletin of the Entomological Society of America, 35: 22-35.

Ekpo, A.S. (2004). Effects of Processing on the Chemical Composition of Maize. $24^{\text {th }}$ Annual

Conference of Nigeria Society of Biochemistry and Molecular Biology. University Of Calabar. Nov $24^{\text {th }}-27^{\text {th }}$.

Ekpo EA, Udoh AL, and Akpan PE (2010). Proximate and anti-nutrient composition of flour edible insects in Akwa Ibom State, Nigeria. World J. Appl. Sci. Technol. 2 (2): 224-231. 
Ezeagu, I.E. (2005). Baobab (Adansonia digitata) seed protein utilization in young albino rats I: Biochemical ingredients and performance characteristics. Anim. Res. Int. 2(1): 240245.

Fasoranti, J.O., (1997). The value of African insects as human food supplements. J. Sci. Tech., 10 :

$1-5$.

Fasoranti, J.O. and Ajiboye DO (1993). Some edible insects of Kwara state, Nigeria. Amer. Entomol. 39:113 -116.

Groff J, Gropper S, Hunt S (1995). Advanced Nutritional and Human Metabolism. $2^{\text {nd }}$ ed., New York. Pp. 221-362.

Harbourne J.B.C. (1973). Phytochemical Method, Chapman And Hall, London P. 279.

Iwe, M.O (2002). Handbook of Sensory methods and analysis. Rojoint Com. Services Ltd. Enugu, Nigeria

Iwe, M.O. (2007). Current trends in sensory evaluation of foods. Rojoint comm. Services Ltd,

Enugu. P 46-47.

Idolo, I. (2010). Nutritional and Quality Attributes of Wheat Buns Enriched with the Larvae of Rhynchophorus phoenicis F. Pakistan Journal of Nutrition 9 (11): 1043-1046

Ifie I, Emeruwa CH (2011). Nutrietional and antinutrtional characteristics of the larva of oryctes

monoceros. Agric. Biol. J. N. Am., 2 (1); $42-46$.

Igwe, C.U., Onwuliri, V.A., Ojiako, A.O., and Arukwe, U. (2011). Effects of Macrotermes nigeriensis Based Diet on Heoatic and Sesum Lipids of Albino Rats. Australian K Basic \& Appl. Scs. 5: 906-910

Igwe, C. U, Ujonwundu C.O, Nwaogu L.A., and Okwu C. N. (2011). Chemical Analyisi of An

Edible Termite, Macrotermes nigeriensis; A Potential Antidote to Food Security Problem Biochem

and Anal Biochem. 1: 105. Doi: 10. 4172/2161-1009. 1000105.

Ihekoronye, A.I., and Ngoddy, P.O. (1985). Integrated food science and technology for the tropics. 1st ed. McMillan publishers. pp. 261- 291.

James S.C (1995) Analytical chemistry of Roots Chaman and hall, New York. Pp 2830

Kiin-Kabari D.B. and Ogbonda K.H (2013). Production, Proximate and Sensory Evaluation of Rhynchophorus Phoenicis (F) Larva paste. Journal of Food Studies., 2(1): $13-18$
Kinyuru, J.N, Kenji, G.M., and Njoroge, M.S. ( 2009). Process development, nutrition and sensory qualities of wheat buns enriched with edible termites (Macrotermes subhylanus) from lake Victoria region, Kenya. African Journal of Food Agriculture Nutrition and Development. 9 (8): 1739 1750

Kirk, R. and Sawyer, R.(1998). Pearson's composition and analysis of foods. Church Hill Livingstone, dinbburgh.

Lyon, W. F. (1991). Insects as Food. Ohio State University Extension Fact sheet. Retrieved from www.ohioline.osu.edu

Mbah C.E., Elekima G.O.V. (2007). Nutrient Composition Of Some Terrestrial Insects In Ahmadu Bellow University, Samara Zaria, Nigeria. Science World J. 2:17-20

Mcwillien, M. (1978). Food fundamental 3rd edition. California State University Los Angeles. P .27-29.

Messiaen, C. M. (1992). The tropical vegetable garden. Maemillian ltd. London and Basing stoke. P 218-247.

Malaisse F. and parent G. (1980) les chenilles comestibles du Shaba meridinal Naturalistes Belg. 61, $2-24$.

Meyer-Rochow, V. B. (2010). Entomophagy and its impacts on World cultures: the need for a multidisciplinary approach. In P. B. Durst, D. V. Johnson, R. N. Leslie, \& K. Shono. (Eds.), Forest Insects as food: Humans bite back. Proceeding of a workshop on Asia Pacific resources and their potential for development. 19-21 February 2008, Chiang Mai, Thailand. FAO 2010.

Motshegwe, S.M., Holnback, J. and Yeboah, S.O. (1998). General properties and fatty Acid composition of the oil from the Mopare caterpillar, Imbresia belina J. Amer oil Chem Soc 75:725 - 728 .

Min, D. B. and Boff, J. M. (2003). Crude Fat Analysis, In "Food Analysis". 3rd Edition.

Ndubuakaku VO, Uwangbute AC, Nnayelugo DO (1989). Flatulence and other abdominal dis comforts associated with Cowpea. Appitite. 13: 171-181.

Ojiako OA, Igwe CU (2006). The nutritive, antiOnutritrive and hepatotoxic properties of Trichosanthes anguina (Snake Tomato) fruits from Nigeria, Pak $J$ Nutr 7: 85-89.

Ojiako OA, Igwe CU, Agha NC, Ogbuji CA, Onwuliri VA (2010) Protein and Amino aci compositions of Sphensostylis Stenocarpa, Sesamum indicum, Monodora Myristica and Afzelia Africana seeds from Nigeria. Pak $J$ Nutr 9: 368-373.

Olaofe, O., Arogundade, L. A., Adeleye, E. J., and Falusi, O. M. (1998). Composition and food 
properties of the Variegated grasshopper, Zonocerus variegatus. Trop. Sci., 33, 233237.

Olutiola, P. O., O. Famurewa and Sonntag, H.G. (1991). An Introduction to General Microbiology,

A practical approach $1^{\text {st }}$ Edn., Heidelberger Verlagsanstatt and Druckerei Gmbh Heidelberg, Germany, ISBN: 3-894-042-4.

Onwuka, G.I. 2005. Food Analysis and instrumentation: Theory and practice. Naphthali Prints, Lagos, Nigeria. Pg. 45 -144.

Pearson D (1973). Laboratory Techniques in Food Analysis, Butter-worths, London. Pp. 33-52.

Raksakantong P., Meeso N., Kubola J., and Siriamornpun, S. (2010). Fatty acids and proximate composition of eight Thai edible terricolous insects. Food Res. Int. 43: 350355.

Rickard O and P Sjodin (1984). Effect of Maillard reaction products on protein digestion. In Vivo studies on rats. J. of Nutr. 1984; 114: $2228-2234$.

Saris, N. E., E. Mervaala, H. Karppanen, J.A. Khawaja and Lewenstam, A. (2000). Magnesium: An update on physiological, clinical and analytical aspects. Clinical Chimica Acta, 294: 1-26.

Talwar, G.P., Srivastava, L.M., and Mudgil, K.D. (1989). Textbook of Biochemistry and Human Biology. Prentice Hall of India Private Limited, India.
Teffo LS, Toms RB, Eloff JN (2007). Preliminary Data on the Nutritional Composition of EdibleStink-Bug, Ericosternum delegorguei Spino, Consumed In Limpopo Province, South Africa. South Afri. J. Sci. 103: 434 436.

Topping, D.L., Stwer, G.B, Calvert, G.D and R.D. Meller (1980). Effect of Dietary Saponins on fecal bile acids and neutral sterols, plasms lipids and lipoprotein tumous in the Pig. Am. J. Ani. Nutr. 33: $783-786$

Uraih, N. and Izuagbe, Y. (1990). Public Health, Food and Industrial Microbiology. $1^{\text {st }}$ Edn., Uniben press; Nigeria ISBN: 978-2027-006.

Walter, W. M, Purcell, E, Hoover, W. and White, G. (2006). Preparation and storage of sweet potato flakes fortified with plant protein concentrates and isolates. J. of Food Sci. 2006: 43 (2): 407- 419.

Watt, B. K and Merril, 1963. Consumption of food: raw, processed and prepared. U. S. Dept. Agric. Handbook, 8:1-189.

Watt, B. M. G.L.Ylimki, L.E. Jeffery and L.G Ekics, (1989). Basic Sensory methods for food evaluation international Development research Centre, Ottaria, Ontario, Canada Pp: 68 -97.

WHO. (1999). Global Database on Child Growth and Malnutrition. WHO, Geneva.

Yoloye, V. L. (1988). Basic invertebrate Zoology. University of Ilorin Press, Ilorin, Nigeria. 